\title{
The potential role of exhaled breath analysis in the diagnostic process of pneumonia - a systematic review
}

DOI:

10.1088/1752-7163/aaa499

\section{Document Version}

Accepted author manuscript

Link to publication record in Manchester Research Explorer

\section{Citation for published version (APA):}

van Oort, P., Povoa, P., Schnabel, R., Dark, P., Artigas, A., Bergmans, D., Felton, T., Coelho, L., Schultz, M. J., Fowler, S. J., \& Bos, L. (2018). The potential role of exhaled breath analysis in the diagnostic process of pneumonia - a systematic review. Journal of Breath Research. https://doi.org/10.1088/1752-7163/aaa499

\section{Published in:}

Journal of Breath Research

\section{Citing this paper}

Please note that where the full-text provided on Manchester Research Explorer is the Author Accepted Manuscript or Proof version this may differ from the final Published version. If citing, it is advised that you check and use the publisher's definitive version.

\section{General rights}

Copyright and moral rights for the publications made accessible in the Research Explorer are retained by the authors and/or other copyright owners and it is a condition of accessing publications that users recognise and abide by the legal requirements associated with these rights.

\section{Takedown policy}

If you believe that this document breaches copyright please refer to the University of Manchester's Takedown Procedures [http://man.ac.uk/04Y6Bo] or contact uml.scholarlycommunications@manchester.ac.uk providing relevant details, so we can investigate your claim.

\section{OPEN ACCESS}


ACCEPTED MANUSCRIPT

\section{The potential role of exhaled breath analysis in the diagnostic process of pneumonia - a systematic review}

To cite this article before publication: Pouline van Oort et al $2018 \mathrm{~J}$. Breath Res. in press https://doi.org/10.1088/1752-7163/aaa499

\section{Manuscript version: Accepted Manuscript}

Accepted Manuscript is "the version of the article accepted for publication including all changes made as a result of the peer review process, and which may also include the addition to the article by IOP Publishing of a header, an article ID, a cover sheet and/or an 'Accepted Manuscript' watermark, but excluding any other editing, typesetting or other changes made by IOP Publishing and/or its licensors"

This Accepted Manuscript is @ 2018 IOP Publishing Ltd.

During the embargo period (the 12 month period from the publication of the Version of Record of this article), the Accepted Manuscript is fully protected by copyright and cannot be reused or reposted elsewhere.

As the Version of Record of this article is going to be / has been published on a subscription basis, this Accepted Manuscript is available for reuse under a CC BY-NC-ND 3.0 licence after the 12 month embargo period.

After the embargo period, everyone is permitted to use copy and redistribute this article for non-commercial purposes only, provided that they adhere to all the terms of the licence https://creativecommons.org/licences/by-nc-nd/3.0

Although reasonable endeavours have been taken to obtain all necessary permissions from third parties to include their copyrighted content within this article, their full citation and copyright line may not be present in this Accepted Manuscript version. Before using any content from this article, please refer to the Version of Record on IOPscience once published for full citation and copyright details, as permissions will likely be required. All third party content is fully copyright protected, unless specifically stated otherwise in the figure caption in the Version of Record.

View the article online for updates and enhancements. 
1 The Potential Role of Exhaled Breath Analysis in the Diagnostic Process of Pneumonia - A Systematic Review

3 Pouline M. P. van Oort ${ }^{1^{*}}$, Pedro Povoa ${ }^{2,3}$, Ronny Schnabel ${ }^{4}$, Paul Dark ${ }^{5}$, Antonio

4 Artigas $^{6}$, Dennis C.J.J. Bergmans ${ }^{4}$, Timothy Felton ${ }^{5}$, Luis Coelho ${ }^{2,3}$, Marcus J.

5 Schultz $^{1}$, Stephen J. Fowler ${ }^{5}$ and Lieuwe D. Bos ${ }^{1}$ on behalf of the BreathDx

6 Consortium $^{+}$

7

$8{ }^{1}$ Department of Intensive Care, Academic Medical Centre, Amsterdam, The

9 Netherlands

$10{ }^{2}$ Hospital de São Fransisco Xavier, Centro Hospitalar Lisboa Ocidental, Lisbon,

$11 \quad$ Portugal

$12{ }^{3}$ NOVA Medical School, CEDOC, New University of Lisbon, Lisbon, Portugal

$13{ }^{4}$ Maastricht University Medical Centre+, Maastricht, The Netherlands

$14{ }^{5}$ Division of Infection, Immunity and Respiratory Medicine, School of Biological

15 Sciences, Faculty of Biology, Medicine and Health, Manchester Academic Health

16 Science Centre, The University of Manchester and University Hospital of South

17 Manchester, NHS Foundation Trust, Manchester UK

$18{ }^{6}$ Critical Care Department, CIBER Enfermedades Respiratorias, Corporacion

19 Sanitaria Universitaria Parc Tauli, Sabadell, Spain

* Correspondence: Pouline M.P. van Oort, Dept of Intensive Care, Academic Medical

Centre, Meibergdreef 9, 1105 AZ Amsterdam, The Netherlands. Email: pouline.vanoort@gmail.com

$25{ }^{+}$A list of all members of the BreathDx Consortium: Waqar Ahmed, Antonio Artigas,

Dennis C.J.J. Bergmans, Lieuwe D. J. Bos, Marta Camprubi, Luis Coelho, Paul Dark,

27 Alan Davie, Emili Diaz, Gemma Goma, Timothy Felton, Stephen J. Fowler, Royston 
28 Goodacre, Hugo Knobel, Oluwasola Lawal, Jan-Hendrik Leopold, Ignacio Martin-

29 Loeches, Tamara Nijsen, Pouline M. P. van Oort, Pedro Povoa, Craig Johnson,

30 Nicholas J. W. Rattray, Guus Rijnders, Ronny Schnabel, Marcus J. Schultz, Ruud

31 Steenwelle, Peter J. Sterk, Jordi Valles, Fred Verhoeckx, Anton Vink, Hans Weda,

32 Tineke Winters, Tetyana Zakharkina

33

34 Word count abstract: 237

35 Word count text: $\mathbf{3 1 8 3}$

36 Running Title: Exhaled Breath Analysis for Diagnosis of Pneumonia 


\section{Abstract}

38 Diagnostic strategies currently used for pneumonia are time-consuming, lack 39 accuracy and suffer from large inter-observer variability. Exhaled breath contains 40 thousands of volatile organic compounds (VOCs), which include products of host and 41 pathogen metabolism. In this systematic review we investigated the use of so-called 42 'breathomics' for diagnosing pneumonia.

43 A Medline search yielded 18 manuscripts reporting on animal and human studies 44 using organic and inorganic molecules in exhaled breath, that all could be used to 45 answer whether analysis of VOC profiles could potentially improve the diagnostic 46 process of pneumonia. Papers were categorised based on their specific aims; the 47 exclusion of pneumonia; the detection of specific respiratory pathogens; and whether 48 targeted or untargeted VOC analysis was used.

49 Ten studies reported on the association between VOCs and presence of pneumonia. 50 Eight studies demonstrated a difference in exhaled VOCs between pneumonia and 51 controls; in the individual studies this discrimination was based on unique sets of 52 VOCs. Eight studies reported on the accuracy of a breath test for a specific 53 respiratory pathogen: five of these concerned preclinical studies in animals. All 54 studies were valued as having a high risk of bias, except for one study that used an 55 external validation cohort.

56 The findings in the identified studies are promising. However, as yet no breath test 57 has been shown to have sufficient diagnostic accuracy for pneumonia. We are in 58 need of studies that further translate the knowledge from discovery studies to clinical 59 practice.

60

62 Key words: Exhaled breath analysis; Pneumonia; Diagnosis; Breathomics; Volatile Organic Compounds

\section{4}




\section{Introduction}

The prevalence of community-acquired pneumonia $(\mathrm{CAP})^{1}$ and nosocomial pneumonia ${ }^{2,3}$ is high with substantial impact on morbidity and mortality ${ }^{4-10}$. Treatment of pneumonia is a balance between optimal antibiotic therapy for the patient (e.g. a combination of antibiotics that effectively target the causative pathogen) and for the community (e.g. minimizing the duration of exposure to broad spectrum antibiotics to limit antimicrobial resistance $)^{11}$. In the ideal world, this balance would be met through a diagnostic test that is not only quick, non-invasive, reliable and available in realtime at the bedside, but most of all (1) excludes pneumonia in order to withhold antibiotic treatment from patients without an infection; (2) enables targeting of antibiotic treatment of the causative pathogen; and (3) facilitates evaluation of the treatment response aiming to refine antibiotic de-escalation and duration of antibiotic treatment.

'Breathomics' refers to the analysis of volatile compounds in exhaled breath that resulted from, or are affected by metabolism ${ }^{12}$. The complete human breathome consists of thousands of compounds ${ }^{13-17}$. The volatile organic compounds (VOCs) that are present in the exhaled breath have various origins. Exogenous VOCs are derived from the environment and are taken in through inhalation or ingestion (e.g. via food or drugs). VOCs that are produced within the body can emerge as products of physiological metabolic processes from the host, as products of metabolic processes from microbial pathogens, or results from of a host response to pathological processes such as infection or inflammation ${ }^{18-20}$. Changes, therefore, in host or microbial metabolism might lead to an impact on the composition of the exhaled breath profile.

In this systematic review we aim to investigate the potential role of exhaled breath analysis for diagnosing pneumonia, by providing: (1) sensitive detection of pneumonia; (2) specific detection of the causative organism(s); and (3) a tool to

92 monitor the treatment response after the initiation of antibiotics (see Figure 1). We 
93 hypothesize that changed concentrations of VOCs in exhaled breath can be used to

94 accurately discriminate patients with pneumonia from patients without pneumonia

95 and may be used for specific identification of the causative pathogen.

Methods

$\underline{\text { Search }}$

99 This is a systematic review following PRISMA (Preferred Reporting Items for

100 Systematic Reviews and Meta-Analyses) guidelines, performed by two independent

101 researchers. We searched Medline for potentially relevant articles up to March $7^{\text {th }}$

102 2017, using the following search terms: "(((Chromatography OR Spectrometry OR

103 MS OR (Volatile AND Organic) OR Metabol ${ }^{\star}$ ) AND breath) OR (volatile fingerprint ${ }^{\star}$ )

104 OR (breathprin*) OR (electronic AND nose)) AND (pneumonia OR (lung infection*)

105 OR (respiratory infection*) OR (lung bacteria*) OR (respirator* bacteria*))". There

106 was no restriction with respect to human or animal studies; but articles written in a

107 language other than English and studies performed in vitro were excluded. Two

108 authors ( $P v O$ and $\mathrm{LB}$ ) reviewed the abstracts and/or full-text manuscripts

109 independently and selected those that were regarded to be relevant. No

110 disagreement on selection of articles was seen between the two reviewers.

\section{Selection criteria}

112 Inclusion criteria were (1) human or animal studies that (2) studied volatiles in

113 exhaled breath to (3) diagnose bacterial pneumonia or identify the causative

114 organism of pneumonia. Objective 3 as mentioned in the introduction (the evaluation

115 of the treatment effect in patients with pneumonia) was let go, due to a lack of

116 studies specifically investigating this. We excluded in vitro studies and studies that

117 focused on very specific atypical causative organisms (such as Aspergillus).

\section{Reference test}

119 The diagnosis of pneumonia could be based on clinical symptoms alone, or could be

120 supported by chest radiography and/or microbiology testing (cultures of endotracheal 
121 aspirate (ETA), nondirected bronchial lavage (NBL or mini-BAL) or bronchoalveolar 122 lavage $(B A L))$. For community-acquired pneumonia, the combination of clinical signs 123 and symptoms with an evident infiltrate on the chest radiograph was considered a 124 good reference test, while anything less was considered too nonspecific. For 125 ventilator-associated pneumonia, clinical signs, laboratory parameters, an infiltrate 126 on chest radiography and quantitative cultures of BAL or NBL were considered án 127 appropriate reference standard.

$128 \underline{\text { Index test }}$

129 Advances in chemical analytics have enabled the measurement of inorganic ${ }^{21,22}$ and 130 organic compounds ${ }^{23-25}$ in biological matrices such as exhaled breath. Volatile 131 molecules in breath can be studied via a targeted and an untargeted approach ${ }^{12}$. 132 With the targeted approach the researcher identifies the molecules of interest 133 beforehand and uses analytical assays to measure those compounds quantitatively. 134 The untargeted approach entails analytical techniques that measure multiple 135 molecules present in the breath. Untargeted analysis can be performed with mass136 spectrometry based techniques aimed to identify a variety of $\mathrm{VOCs}^{26}$ or with so137 called electronic nose technology that is based on pattern recognition ${ }^{14,27,28}$. The 138 analytical details of these techniques are discussed in detail in previous 139 publications ${ }^{27,29}$. Figure 2 summarises the analytical methods that will be referred to 140 in this systematic review. No single method is superior to the others, they provide 141 different types of information, therefore the quality of the index test was assessed 142 based on the use of an independent validation cohort, which has been shown to limit 143 bias $^{27}$.

144 Methodological assessment and categorisation

145 The methodological quality of each selected full manuscript was evaluated using the 146 QUADAS-2 tool by the same authors as describes above ${ }^{30}$. Risk of bias was 147 assessed concerning patient selection, the interpretation or conduct of the index test, 148 the interpretation or conduct of the reference standard and the patient flow. The 
149 papers were classified as either (1) studies concerning sensitive detection of the 150 presence of pathogenic bacteria, either concerning studies investigating inorganic 151 compounds, untargeted analysis of VOCs or eNose technology for discrimination 152 between pneumonia and no pneumonia; or (2) studies investigating the use of VOC 153 analysis for specific detection of pathogenic bacteria, in animals or in humans.

154

155

156

\section{Results}

The search was last updated on March $7^{\text {th }} 2017$ and yielded 321 articles, of

158 which 18 were selected after screening on title/abstract and full text/Figure 3). Of 159 these, 13 studies were in humans and five were performed in murine models. Eight 160 studies dealt with the detection of specific pathogenic bacteria, the others focused on 161 discrimination between patients with and without pneumonia. One of the studies 162 discussed treatment response. Table 1 demonstrates the areas of interest for each 163 study and summarises the methodology used.

164 The studies were critically appraised and risk of bias was assessed regarding 165 patient selection, index test, reference standard and flow and timing (Table 2). The 166 domain 'patient selection' was considered not applicable in the five animal studies. 167 For most studies the risk of bias was valued as high, except for one that used a 168 validation cohort ${ }^{31}$, resulting in a low risk of bias regarding the index test.

170 Discrimination between patients with and without pneumonia

171 Detection of volatile inorganic compounds

172 NO was not increased in the breath of a small group of patients admitted with 173 pneumonia, when compared with control patients ${ }^{32}$. As expected it was elevated in 174 patients with an exacerbation of asthma. This result was in contrast to the results of a 175 larger study at less risk of bias (Table 2) in which exhaled NO was measured in 176 tracheal and nasal gas in patients ventilated within 72 hours of ICU admission ${ }^{31}$. 
177 Some of these patients were later diagnosed with VAP and this was used as the

178 reference standard. A validation cohort consisting of similar patients to the first group

179 was used to determine sensitivity and specificity of the NO threshold that was 180 calculated in the preceding group. NO concentrations were measured at multiple 181 sampling points in the airway as well as in the nasal cavity, and significantly higher 182 NO levels were found at all points in patients with pneumonia. Of these, the 183 maximum (end-expiratory) tracheal NO values resulted in the highest sensitivity and 184 specificity for the diagnosis of pneumonia: $88 \%$ and $76 \%$ respectively (see Table 1). 185 Results from one study with an imperfect reference test, namely subjective 186 symptoms of lower respiratory infection, suggested a possible relationship between 187 elevated exhaled CO levels and the clinical presence of pneumonia ${ }^{33}$. Notably, the 188 exhaled CO concentration followed similar trends as the patients' symptoms after 189 antimicrobial treatment.

191 Untargeted analysis of VOCs

192 The abundance of particular VOCs seems to be different in the breath of 193 mechanically ventilated patients with pneumonia compared with those without 194 pneumonia ${ }^{34-36}$. The results of studies using gas chromatography and mass 195 spectrometry (GC-MS, see Figure 2), however, were not uniform. The described 196 VOCs differed between studies and two compounds that were identified as being 197 associated with VAP (ethanol and heptane) showed conflicting results in two studies 198 (as shown in Table 3). Differences between studies regarding investigated cohorts, 199 reference standards and outcome measures (sensitivity, specificity and/or accuracy) 200 can be found in Table 1. Nevertheless, breath tests showed promising discrimination 201 between patients with and without pneumonia in the included clinical studies. The 202 most frequently isolated pathogens in these studies were Staphylococcus aureus, 203 Haemophilus influenzae, Pseudomonas aeruginosa, Escherichia coli and Klebsiella 204 pneumoniae $34-36$. 
206 Electronic nose technology

207 Preliminary results indicated a potential correlation between chest CT scans $^{37}$ or 208 Clinical Pulmonary Infection Score (CPIS) ${ }^{38}$ and the subsequent eNose sensor 209 responses in mechanically ventilated patients. The eNose (see Figure 2) seemed to 210 distinguish patients with and without bacterial infection ${ }^{39}$ (Table 1). When specifically 211 focusing on diagnosis of VAP, the eNose appeared to have good accurracy, 212 moderate sensitivity and a rather poor specificity ${ }^{40}$.

214 Specific detection of pathogens by VOC analysis

216 Figure 2) breathprint analysis was used to investigate the ability to identify respiratory 217 infection caused by strains of Haemophilus influenzae, Klebsiella pneumoniae, 218 Legionella pneumophila, Moraxella catarrhalis, Pseudomonas aeruginosa, 219 Staphilococcus aureus or Streptococcus pneumoniae in mice ${ }^{41-44}$. Overall SESI-MS 220 breathprints seemed to be able to distinguish between respiratory infection and no 221 infection in mice and enabled differentiation between strains of aforementioned 222 pathogens. A high degree of variation was seen when translating in vitro experiments 223 to the in vivo VOC fingerprints ${ }^{42}$. The relative contribution of bacterial metabolism and 224 host response on the exhaled breath profile could be inferred through an experiment 225 in which mice were exposed to bacterial cell lysates ${ }^{45}$. This experimental set-up, 226 using these bacterial cell lysates, allows for host and pathogen derived metabolites 227 to be differentiated. The obtained SESI-MS breathprints changed over time after 228 lysate exposure and appeared to 1) correlate to the host immune response; and 2) 229 distinguish active infections of $P$. aeruginosa or $S$. aureus from cell lysate exposure. 230 Also using GC-MS specific VOCs in the exhaled breath seemed to reflect the 231 presence of particular microorganisms in the respiratory tract and, in line with the use 232 of SESI-MS, direct translation of biomarkers from the in vitro to the in vivo setting 
233 proved difficult ${ }^{46,47}$. In clinical studies, the evidence for specific detection of particular

234 causative pathogens seemed speculative; as the published papers did not provide 235 data on the accuracy of such measurements ${ }^{46}$. The only study that reported a high 236 diagnostic accuracy for the identification of a causative pathogen focused on 237 Acinetobacter baumannii. A set of eight compounds resulted in excellent separation 238 of patients with A. baumannii pneumonia, colonization with the same bacterium and 239 controls. The major limitation of the described studies was that they did not evaluate 240 the diagnostic accuracy of a breath test in the clinical scenario where such a test 241 would be used; e.g. in patients with a clinical suspicion of VAP.

\section{Discussion}

243 Based on our systematic review, the presence of certain profiles or patterns 244 of volatile molecules in the exhaled breath appeared to be associated with 245 pneumonia. However, the precise identity of these volatile biomarkers remains 246 largely unknown. Furthermore, none of the studied breath tests delivered results with 247 sufficient clinical diagnostic accuracy that would likely impact on clinical decisions. 248 Most of the available studies provided feasibility or proof of concept data with a 249 substantial risk of bias and did not test a clear, pre-defined hypothesis.

250 There are two leads to follow in the diagnosis of pneumonia: measurement of 251 the host response or direct identification of the pathogen ${ }^{48,49}$, both important 252 establishing the ideal diagnostic test. In vitro results suggested that different 253 pathogenic bacteria produced different volatile molecules, which might be used for 254 identification ${ }^{20}$. One of the major challenges is that bacterial growth and metabolism 255 are influenced by the chosen culture media, timing and the selection of particular 256 strains and, therefore, may not be representative of growth in vivo ${ }^{20}$. A sterile 257 inflammatory response altered the VOC release in several animal models of lung 258 injury ${ }^{21}$. Thus, pneumonia may be recognized through exhaled breath analysis by 259 detection of molecules produced either directly by the pathogen or through an altered 260 host metabolism associated with the host response. Animal studies might offer 
261 advantages enabling the investigation of 1) a single bacterial infection, 2) the

262 influence of timing on disease progression and 3) post-mortem histology for the gold263 standard diagnosis of respiratory infection.

264 This systematic literature review demonstrates that certain volatile molecules 265 could be useful as possible biomarkers for the diagnosis of pneumonia. One of them 266 is nitric oxide (NO), a compound that has a bronchodilating and vasodilating effect in 267 the respiratory tract and plays a key role in local inflammatory response ${ }^{22}$. NO is 268 relatively easy to measure and thus forms an attractive candidate for diagnostic 269 purposes ${ }^{50,51}$. In the airways $\mathrm{NO}$ is produced by endothelial, epithelial and 270 inflammatory cells. Generation of NO involves the oxidation of the aminoacid L271 arginine, a process that is catalysed by the enzyme NO synthase ${ }^{52}$. An increased 272 concentration of exhaled NO is seen in asthma, bronchiectasis and $\operatorname{sepsis}^{53}$, and has 273 also been associated with rhinitis, active pulmonary sarcoidosis and viral respiratory 274 illnesses ${ }^{52}$. Table 3 shows other biomarkers of potential interest regarding the 275 discrimination of patients with and without pneumonia. However, hardly any overlap 276 is seen between the different VOCs reported in separate studies and they also show 277 conflicting results for heptane and ethanol. Two studies found an association 278 between pneumonia and a decrease in exhaled breath acetone. Generally, acetone 279 is present in large quantities in the exhaled breath. Its decrease in the breath of 280 pneumonia patients might be explained by a reduced ketogenesis that is seen during 281 inflammation or infection ${ }^{34}$.

282 As soon as a breath test fulfils the requirements for a diagnostic test for 283 pneumonia, it shall be able to fulfil a role alongside the currently available and 284 frequently used alternatives ${ }^{54,55}$ and can either compete with them, or complement 285 them. The diagnosis of pneumonia relies on a combination of physical examination 286 and chest radiography ${ }^{56}$, potentially accompanied by measurement of inflammatory 287 markers in plasma, urinary antigen testing ${ }^{54}$, repeated determination of C-reactive 288 protein $(\mathrm{CRP})^{57}$ and collecting airway samples for microbiology cultures ${ }^{58}$. Current 
289 diagnostics lack clinical accuracy $^{59}$ and have high inter-observer variability ${ }^{60}$.

290 Microbiology results take 48-72 hours to become positive. The unnecessary 291 prescription of antimicrobial treatment increases antimicrobial resistance ${ }^{61-63}$, 292 whereas applying the wrong antibiotics is likely to increase mortality ${ }^{64-66}$. In order to 293 withhold antibiotics, the $\mathrm{CPIS}^{67}$ combines clinical and physiological data, pulmonary 294 radiography and microbiology results into a numeric score that can be used to 295 exclude pneumonia with moderate accuracy due to substantial inter-observer 296 variability ${ }^{68,69}$. Additionally, biomarkers like pulmonary interleukin-1 $\beta$ (IL-1 $\beta$ ) and 297 interleukin-8 (IL-8) measured in BAL fluid have shown promising results as 298 discriminators for VAP70,71. In the near future Polymerase Chain Reaction (PCR) of 299 respiratory samples might be used to identify the causative pathogen rapidly and 300 specifically $^{72-74}$ and serum procalcitonin has been proposed as an attractive 301 candidate for determining antibiotic duration ${ }^{75,76}$. How would exhaled breath analysis 302 compete with these alternatives? In contrast to blood or BAL samples, breath can be 303 collected completely non-invasive and it is continuously available. A breath test could 304 also provide results rapidly and cost-effectively, which is important in the setting of 305 pneumonia. A breath test with the right test characteristics could thus provide real 306 opportunities for improved real-time diagnostic utility, patient acceptability and cost 307 effectiveness.

308 Many different methods for breath sampling have been described in literature, 309 including but not limited to: glass syringes, needle traps ${ }^{77}$ steel or glass tubes filled 310 with sorbent material and/or breath gas bags (e.g. Tedlar bags). Pre-concentration of 311 the breath sample could be established through the absorption of the VOCs using for 312 instance organic polymers (e.g. Tenax TA), graphitized carbon, activated charcoal or 313 carbon molecular sieves ${ }^{78}$. A challenge in the process of breath sampling is the 314 humidity of exhaled breath - especially true for mechanically ventilated patients 315 which possibly affects pre-concentration, separation and detection of individual 316 compounds $^{16}$. The use of storage containers such as Tedlar Bags has been linked to 
317 loss of analytes or contamination of samples ${ }^{77}$. The lack of standardization of 318 analytical methods leads to a wide variation of results among studies. Application of 319 a standardised method of exhaled breath analysis would lead to comparable results, 320 thereby facilitating the potential use of breath biomarkers in the future ${ }^{79}$.

321 Based on the results from the studies included in this review, we can 322 conclude that the VOCs that are measurable in exhaled breath are altered during 323 pneumonia and can derive from the bacterial metabolism as well as the host 324 response. However, these results do not yet allow us to link specific compounds to 325 particular pathogens or disease states, nor does it allow us to pool data from different 326 experiments or studies due to bias and heterogeneity in experimental procedures. 327 Future studies should utilize this understanding and not only focus on VOCs 328 produced by bacteria or the host, but should also combine these two for optimal 329 diagnostic accuracy. Additionally, a more stringent approach towards the 330 methodological design of the studies is recommended. This includes following the 331 STARD guidelines for reporting studies on diagnostic accuracy to limit the amount of 332 bias $^{80,81}$. Previous reviews ${ }^{27,82}$ properly summarised the necessary steps to validate 333 preliminary results in breath research. Importantly, future studies should focus more 334 on the clinical application of a breath test. As advocated in this review such a test 335 would 1) exclude pneumonia in order to withhold antibiotic treatment from patients 336 without an infection; 2) enable targeting of antibiotic treatment to the causative 337 pathogen; and/or 3) facilitate evaluation of the treatment response aiming to refine or 338 stopping antibiotics. To date, most focus has been on VAP rather than on 339 community-acquired pneumonia, implicating that currently most evidence is available 340 for this particular respiratory infection aetiology. Therefore, this might also be the 341 clinical problem that might require direct focus in the forthcoming years of breath 342 research.

343 This systematic review of the literature has several strengths and 344 weaknesses. We chose to apply wide inclusion criteria in order to fully cover the 
345 literature in this relatively nascent field of research. Naturally, this resulted in a wide

346 diversity of selected articles and made it impossible to pool data due to the

347 underlying heterogeneity, which can be seen as a limitation of our review. In general

348 one can also wonder to what extent the results provided by animal experiments can

349 be translated to the human situation. This study also has several strengths: clinical

350 and pre-clinical studies with multiple analytical devices were included and the results

351 were clustered into the clinical perspective of three scenarios where a biomarker

352 could alter clinical decision-making.

353 This review demonstrates that a relationship exists between respiratory

354 infection and the presence of particular VOCs in the exhaled breath. Presently, no

355 available breath test is accurate enough to qualify for a role within the diagnostic

356 process of pneumonia. Future studies should focus on clinical scenarios in which a

357 breath test could impact on antimicrobial stewardship and should limit bias by strictly

358 adhering to the latest guidelines.

359

360 Acknowledgements The authors thank all the members of the BreathDx

361 Consortium: Waqar Ahmed, Antonio Artigas, Dennis C.J.J. Bergmans, Lieuwe D. J.

362 Bos, Marta Camprubi, Luis Coelho, Paul Dark, Alan Davie, Emili Diaz, Gemma

363 Goma, Timothy Felton, Stephen J. Fowler, Royston Goodacre, Hugo Knobel,

364 Oluwasola Lawal, Jan-Hendrik Leopold, Ignacio Martin-Loeches, Tamara Nijsen,

365 Pouline M. P. van Oort, Pedro Povoa, Nicholas J. W. Rattray, Guus Rijnders, Ronny

366 Schnabel, Marcus J. Schultz, Ruud Steenwelle, Peter J. Sterk, Jordi Valles, Fred

367 Verhoeckx, Anton Vink, Hans Weda and T1616ineke Winters.

368 Author Contributions PvO and LB conceptually designed the manuscript and 369 performed the literature search. PvO and LB prepared the initial version of the paper 370 and PP, RS, PD, AA, DB, TF, LC, MS and SF advised on the composition of the 371 subsequent final manuscript. All authors approved the submitted version of this 372 article. PvO can be regarded the guarantor of the paper, taking responsibility for the 
373 integrity of the work as a whole, from incepton to published article.

374 Funding Funding is provided by the European Union: BreathDx -611951.

375 Competing interests None declared

376

377 
378

379 1. Waterer G, Rello J, Wunderink R. Management of community-acquired

380

\section{References} pneumonia in adults. Am J Respir Crit Care Med 2011;183:157-164.

2. American Thoracic Society. Guidelines for the Management of Adults with Hospital-acquired, Ventilator-associated, and Healthcare-associated Pneumonia. Am J Respir Crit Care Med [Internet] 2005;171(4):388-416. Available from: http://www.atsjournals.org/doi/abs/10.1164/rccm.200405$644 S T$

3. Ego A, Preiser J-C, Vincent J-L. Impact of diagnostic criteria on the incidence of ventilator-associated pneumonia. Chest [Internet] 2014;1-28. Available from: http://www.ncbi.nlm.nih.gov/pubmed/25340476

4. Klevens RM, Edwards JR, Richards Jr. CL, et al. Estimating health careassociated infections and deaths in U.S. hospitals, 2002. Public Heal Rep [Internet] 2007;122(2):160-166. Available from: http://www.ncbi.nlm.nih.gov/pubmed/17357358

5. Restrepo MI, Faverio P, Anzueto A. Long-term prognosis in communityacquired pneumonia. Curr Opin Infect Dis [Internet] 2013;26(2):151-8. Available from:

http://www.pubmedcentral.nih.gov/articlerender.fcgi?artid=4066634\&tool=pmc entrez\&rendertype=abstract

6. Rotstein C, Evans G, Born A, et al. Clinical practice guidelines for hospitalacquired pneumonia and ventilator-associated pneumonia in adults. Can $J$ Infect Dis Med Microbiol = J Can des Mal Infect la Microbiol médicale / AMMI Canada [Internet] 2008;19(1):19-53. Available from:

http://www.ncbi.nlm.nih.gov/pubmed/19145262\%5Cnhttp://www.pubmedcentr al.nih.gov/articlerender.fcgi?artid=PMC2610276

7. Kalanuria AA, Zai W, Mirski M. Ventilator-associated pneumonia in the ICU. Crit Care [Internet] 2014;18(2):208. Available from: 
406

407

408

409

410

411

412

413

414

415

416

417

418

419

420

421

422

423

424

425

426

427

428

429

430

431

432

433

http://ccforum.com/content/18/2/208

8. Chastre J, Fagon J. State of the Art Ventilator-associated Pneumonia. Am J Respir Crit Care Med 2002;165(23):867-903.

9. Browne E, Hellyer TP, Baudouin S V, et al. A national survey of the diagnosis and management of suspected ventilator-associated pneumonia. BMJ open Respir Res [Internet] 2014;1(1):e000066. Available from:

http://www.pubmedcentral.nih.gov/articlerender.fcgi?artid=4275666\&tool=pmc entrez\&rendertype $=$ abstract

10. Melsen W, Rovers M, Groenwold R, Bonten M. Attributable mortality of ventilator-associated pneumonia: a meta-analysis of individual patient data from randomised prevention studies. Lancet Infect Dis [Internet] 2013;13(8):665-671. Available from: http://dx.doi.org/10.1016/S14733099(13)70081-1\%5Cnpapers2://publication/doi/10.1016/S14733099(13)70081-1

11. Mandell L, Wunderink RG, Anzueto A, et al. Infectious Diseases Society of America/American Thoracic Society consensus guidelines on the management of community-acquired pneumonia in adults. Clin Infect Dis 2007;44 Suppl 2(Supp/2):S27-72.

12. Bos LD, Sterk PJ, Fowler SJ. Breathomics in the setting of asthma and chronic obstructive pulmonary disease. J Allergy Clin Immunol [Internet] 2016;138(4):970-976. Available from:

http://linkinghub.elsevier.com/retrieve/pii/S009167491630882X

13. Phillips MHJ. Variation in volatile organic compounds in the breath of normal humans. J Chromatogr 1999;(729):75-88.

14. Schee MP van der, Paff T, Brinkman P, Aalderen WMC van, Haarman EG, Sterk PJ. Breathomics in Lung Disease. CHEST J [Internet] 2015;147(1):224. Available from: http://journal.publications.chestnet.org/article.aspx?doi=10.1378/chest.14- 
15. Lacy Costello B de, Amann A, Al-Kateb $\mathrm{H}$, et al. A review of the volatiles from the healthy human body. J Breath Res [Internet] 2014;8(1):14001. Available from: http://www.ncbi.nlm.nih.gov/pubmed/24421258

16. Cao W. Breath Analysis: Potential for Clinical Diagnosis and Exposure Assessment. Clin Chem [Internet] 2006;52(5):800-811. Available from: http://www.clinchem.org/cgi/doi/10.1373/clinchem.2005.063545

17. Fens N, Schee MP van der, Brinkman P, Sterk PJ. Exhaled breath analysis by electronic nose in airways disease. Established issues and key questions. Clin Exp Allergy [Internet] 2013;43(7):705-15. Available from: http://www.ncbi.nlm.nih.gov/pubmed/23786277

18. Sethi S, Nanda R, Chakraborty T. Clinical application of volatile organic compound analysis for detecting infectious diseases. Clin Microbiol Rev 2013;26(3):462-475 .

19. Boots AW, Berkel JJBN van, Dallinga JW, Smolinska A, Wouters EF, Schooten FJ van. The versatile use of exhaled volatile organic compounds in

451 20. Bos LDJ, Sterk PJ, Schultz MJ. Volatile Metabolites of Pathogens: A Systematic Review. PLoS Pathog [Internet] 2013;9(5):e1003311. Available from: http://dx.plos.org/10.1371/journal.ppat.1003311

454 21. Miekisch W, Schubert JK, Noeldge-Schomburg GF. Diagnostic potential of 455 breath analysis-focus on volatile organic compounds. Clin Chim Acta [Internet] 2004;347(1-2):25-39. Available from: http://linkinghub.elsevier.com/retrieve/pii/S0009898104002256

458 22. Yates DH. Role of exhaled nitric oxide in asthma. Immunol Cell Biol 459 $2001 ; 79(2): 178-190$.

460 23. Bos LDJ, Sterk PJ, Schultz MJ. Metabolomics in critically ill patients: focus on 461 exhaled air. In: Vincent J.-L. (Ed.): Annual update in intensive care and 
462

463

464

465

466

467

468

469

470

471

472

473

474

475

476

477

478

479

480

481

482

483

484

485

486

487

488

emergency medicine. Springer; 2012. p. 53-62.

24. Moser B, Bodrogi F, Eibl G, Lechner M, Rieder J, Lirk P. Mass spectrometric profile of exhaled breath—field study by PTR-MS. Respir Physiol Neurobiol [Internet] 2005;145(2-3):295-300. Available from: http://linkinghub.elsevier.com/retrieve/pii/S1569904804000266

25. Wilson A. Advances in Electronic-Nose Technologies for the Detection of Volatile Biomarker Metabolites in the Human Breath. Metabolites [Internet] 2015;5(1):140-163. Available from: http://www.mdpi.com/2218-1989/5/1/140/

26. Filipiak W, Sponring A, Baur MM, et al. Molecular analysis of volatile metabolites released specifically by Staphylococcus aureus and Pseudomonas aeruginosa. BMC Microbiol 2012;12:113.

27. Leopold JH, Bos LDJ, Sterk PJ, et al. Comparison of classification methods in breath analysis by electronic nose. J Breath Res [Internet] 2015;9(4):46002. Available from: http://iopscience.iop.org/article/10.1088/1752-7155/9/4/046002

28. Kant KD van de, Sande LJ van der, Jöbsis Q, Schayck OC van, Dompeling E. Clinical use of exhaled volatile organic compounds in pulmonary diseases: a systematic review. Respir Res [Internet] 2012;13(1):117. Available from: http://respiratory-research.com/content/13/1/117

29. Bos L, Schultz M, Sterk P. A simple breath sampling method in intubated and mechanically ventilated critically ill patients. Respir Physiol Neurobiol [Internet] 2014;191:67-74. Available from:

http://www.sciencedirect.com/science/article/pii/S1569904813003674\#

30. Whiting PF, Rutjes AWS, Westwood ME, et al. QUADAS-2: A revised tool for the quality assessment of diagnostic accuracy studies. Ann Intern Med 2011;155(4):529-536.

31. Adrie C, Monchi M, Dinh-Xuan AT, Dall'Ava-Santucci J, Dhainaut JF, Pinsky MR. Exhaled and nasal nitric oxide as a marker of pneumonia in ventilated patients. Am J Respir Crit Care Med 2001;163(5):1143-1149. 
32. Al-Ali MK, Howarth PH. Exhaled nitric oxide levels in exacerbations of asthma, chronic obstructive pulmonary disease and pneumonia. Saudi Med J [Internet] 2001;22(3):249-253. Available from:

http://ovidsp.ovid.com/ovidweb.cgi?T=JS\&PAGE=reference\&D=med4\&NEWS $=\mathrm{N} \& \mathrm{AN}=11307112$

33. Biernacki WA, Kharitonov SA, Barnes PJ. Exhaled carbon monoxide in patients with lower respiratory tract infection. Respir Med 2001;95(12):10031005.

34. Schnabel R, Fijten R, Smolinska A, et al. Analysis of volatile organic compounds in exhaled breath to diagnose ventilator-associated pneumonia. Sci Rep [Internet] 2015;5(October):17179. Available from: http://www.nature.com/articles/srep17179

35. Fowler SJ, Basanta-Sanchez M, Xu Y, Goodacre R, Dark PM. Surveillance for lower airway pathogens in mechanically ventilated patients by metabolomic analysis of exhaled breath: a case-control study. Thorax [Internet] 2015;320325. Available from: http://thorax.bmj.com/cgi/doi/10.1136/thoraxjnl-2014206273

36. Oort PMP Van, Bruin S De, Weda H, Knobel HH, Schultz MJ, Bos LD. Exhaled Breath Metabolomics for the Diagnosis of Pneumonia in Intubated and Mechanically-Ventilated Intensive Care Unit ( ICU ) -Patients. Int J Mol Sci $2017 ; 18: 1-14$.

37. Hockstein NG, Thaler ER, Torigian D, Miller WT, Deffenderfer O, Hanson CW. Diagnosis of pneumonia with an electronic nose: correlation of vapor signature with chest computed tomography scan findings. Laryngoscope [Internet] 2004;114(10):1701-5. Available from: http://www.ncbi.nlm.nih.gov/pubmed/15454757

38. Hockstein NG, Thaler ER, Lin Y, Lee DD, Hanson CW. Correlation of pneumonia score with electronic nose signature: A prospective study. Ann 
518

519

520

521

522

523

524

525

526

527

528

529

530

531

532

533

534

535

536

537

538

539

540

541

542

543 46. Filipiak W, Beer R, Sponring A, et al. Breath analysis for in vivo detection of 544

545 Otol Rhinol Laryngol 2005;114(7):504-508.

39. Geffen WH van, Bruins M, Kerstjens HAM. Diagnosing viral and bacterial respiratory infections in acute COPD exacerbations by an electronic nose: a pilot study. J Breath Res 2016;10(3):36001.

40. Schnabel RM, Boumans MLL, Smolinska A, et al. Electronic nose analysis of exhaled breath to diagnose ventilator-associated pneumonia. Respir Med [Internet] 2015;Available from: http://linkinghub.elsevier.com/retrieve/pii/S0954611115300615

41. Zhu J, Bean HD, Jimenez-Diaz J, Hill JE. Secondary electrospray ionizationmass spectrometry (SESI-MS) breathprinting of multiple bacterial lung pathogens, a mouse model study. J Appl Physiol 2013;114(11):1544-1549.

42. Zhu J, Bean HD, Wargo MJ, Leclair LW, Hill JE. Detectíng bacterial lung infections: in vivo evaluation of in vitro volatile fingerprints. J Breath Res 2013;7(1):16003.

43. Zhu J, Jimenez-Diaz J, Bean HD, et al. Robust detection of P. aeruginosa and S. aureus acute lung infections by secondary electrospray ionization-mass spectrometry (SESI-MS) breathprinting: from initial infection to clearance. $J$ Breath Res 2013;7(3):37106.

44. Bean HD, Zhu J, Sengle JC, Hill JE. Identifying methicillin-resistant Staphylococcus aureus (MRSA) lung infections in mice via breath analysis using secondary electrospray ionization-mass spectrometry (SESI-MS). J Breath Res 2014;8(4):41001.

45. Bean HD, Jimenez-Diaz J, Zhu J, Hill JE. Breathprints of model murine bacterial lung infections are linked with immune response. Eur Respir J 2015;45(1):181-190. 

Available from: http://stacks.iop.org/1752-

$$
\text { 7163/9/i=1/a=016004?key=crossref.798f068dedadbc97df4cca8b842a921c }
$$

47. Gao J, Zou Y, Wang Y, et al. Breath analysis for noninvasively differentiating Acinetobacter baumannii ventilator-associated pneumonia from its respiratory tract colonization of ventilated patients. J Breath Res 2016;10(2):27102.

48. Murdoch DR. How best to determine causative pathogens of pneumonia. Pneumonia [Internet] 2016;8(1):1. Available from: http://pneumonia.biomedcentral.com/articles/10.1186/s41479-016-0004-z

49. Ginsburg GS, Woods CW. The host response to infection: advancing a novel diagnostic paradigm. Crit Care [Internet] 2012;16(6):168. Available from: http://www.ncbi.nlm.nih.gov/pubmed/23134694

50. Cameli P, Bargagli E, Refini RM, Pieroni MG, Bennett D, Rottoli P. Exhaled nitric oxide in interstitial lung diseases. Respir Physiol Neurobiol 2014;197:4652.

51. Cameli P, Bargagli E, Fossi A, et al. Exhaled nitric oxide and carbon monoxide in lung transplanted patients. Respir Med 2015;109(9):1224-1229.

52. Ricciardolo FLM, Sterk PJ, Gaston B, Folkerts G. Nitric oxide in health and disease of the respiratory system. Physiol Rev 2004;84(3):731-765.

53. Hyde RW, Geigel EJ, Olszowka AJ, et al. Determination of production of nitric oxide by lower airways of humans--theory. J Appl Physiol [Internet] 1997;82(4):1290-1296. Available from: http://www.ncbi.nlm.nih.gov/pubmed/9104867

54. Sinclair A, Xie X, Teltscher M, Dendukuri N. Systematic review and metaanalysis of a urine-based pneumococcal antigen test for diagnosis of community-acquired pneumonia caused by Streptococcus pneumoniae. J Clin Microbiol 2013;51(7):2303-2310.

55. Badoux P, Euser SM, Bruin JP, Mulder PPG, Yzerman EPF. Evaluation of the bioNexia Legionella test including the impact of incubation time extension for 
574

575

576 the detection of Legionella pneumophila serogroup 1 antigen in urine. J Clin Microbiol [Internet] 2017;(March):JCM.02448-16. Available from: http://jcm.asm.org/lookup/doi/10.1128/JCM.02448-16

56. Lim WS, Baudouin S V, George RC, et al. BTS guidelines for the management of community acquired pneumonia in adults: update 2009. Thorax [Internet] 2009;64 Suppl 3(6):iii1-55. Available from:

http://www.ncbi.nlm.nih.gov/pubmed/21502103\%5Cnhttp://www.ncbi.nlm.nih.g ov/pubmed/19783532

57. Póvoa P, Martin-Loeches I, Ramirez P, et al. Biomarker kinetics in the prediction of VAP diagnosis: results from the BioVAP study. Ann Intensive Care 2016;6(1):32.

58. Kalil AC, Metersky ML, Klompas M, et al. Management of Adults With Hospital-acquired and Ventilator-associated Pneumonia: 2016 Clinical Practice Guidelines by the Infectious Diseases Society of America and the American Thoracic Society. Clin Infect Dis [Internet] 2016;ciw353. Available from: http://cid.oxfordjournals.org/lookup/doi/10.1093/cid/ciw353

59. Fàbregas N, Ewig S, Torres A, et al, Clinical diagnosis of ventilator associated pneumonia revisited: comparative validation using immediate post-mortem lung biopsies. Thorax [Internet] 1999;54(10):867-73. Available from: http://www.pubmedcentral.nih.gov/articlerender.fcgi?artid=1745365\&tool=pmc entrez\&rendertype=abstract

60. Masterton RG, Galloway A, French G, et al. Guidelines for the management of hospital-acquired pneumonia in the UK: Report of the working party on hospital-acquired pneumonia of the british society for antimicrobial chemotherapy. J Antimicrob Chemother 2008;62(1):5-34.

61. Neu HC. The crisis in antibiotic resistance. Science [Internet] 1992;257(5073):1064-73. Available from: http://www.ncbi.nlm.nih.gov/pubmed/1509257 
602 62. Goossens H, Ferech M, Stichele R Vander, Elseviers M. Outpatient antibiotic 603 use in Europe and association with resistance: A cross-national database $604 \quad$ study. Lancet 2005;365(9459):579-587.

605 63. Lipsitch M, Samore MH. Antimicrobial use and antimicrobial resistance: A 606 population perspective. Emerg Infect Dis 2002;8(4):347-354.

607

64. Melsen WG, Rovers MM, Bonten MJ. Ventilator-associated pneumonia and 608 609 mortality: a systematic review of observational studies. Crit Care Med [Internet] 2009;37(10):2709-2718. Available from:

613 65. Iregui M, Ward S, Sherman G, Fraser VJ, Kollef MH. Clínical importance of delays in the initiation of appropriate antibiotic treatment for ventilatorhttp://www.ncbi.nlm.nih.gov/pubmed/19885994\%5Cnhttp://graphics.tx.ovid.co m/ovftpdfs/FPDDNCLBABFAPH00/fs046/ovft/live/gv025/00003246/00003246200910000-00005.pdf

67. Pugin J, Auckenthaler R, Mili N, Janssens JP, Lew PD, Suter PM. Diagnosis of ventilator-associated pneumonia by bacteriologic analysis of bronchoscopic associated pneumonia. Chest [Internet] 2002;122(1):262-268. Available from: http://dx.doi.org/10.1378/chest.122.1.262

66. Kuti EL, Patel AA, Coleman CI. Impact of inappropriate antibiotic therapy on mortality in patients with ventilator-associated pneumonia and blood stream infection: A meta-analysis. J Crit Care 2008;23(1):91-100.

626 infection score for ventilator-associated pneumonia: a meta-analysis. Respir 627 Care 2011;56(8):1087-1094.

628 69. Zilberberg MD, Shorr AF. Ventilator-Associated Pneumonia: The Clinical 
629

630

631

632

633

634

635

636

637

638

639

640

641

642

643

644

645

646

647

648

649

650

651

652

653

654

655

656

Pulmonary Infection Score as a Surrogate for Diagnostics and Outcome. Clin Infect Dis [Internet] 2010;51(S1):S131-S135. Available from:

http://cid.oxfordjournals.org/lookup/doi/10.1086/653062

70. Conway Morris A, Kefala K, Wilkinson TS, et al. Diagnostic importance of pulmonary interleukin-1beta and interleukin-8 in ventilator-associated pneumonia. Thorax 2010;65(3):201-207.

71. Hellyer TP, Conway Morris A, McAuley DF, et al. Diagnostic accuracy of pulmonary host inflammatory mediators in the exclusion of ventilator-acquired pneumonia. Thorax [Internet] 2015;70(1):41-47. Available from: http://thorax.bmj.com/lookup/doi/10.1136/thoraxjnl-2014-205766

72. Schulte $\mathrm{B}$, Eickmeyer $\mathrm{H}$, Heininger $\mathrm{A}$, et al. Detection of pneumonia associated pathogens using a prototype multiplexed pneumonia test in hospitalized patients with severe pneumonia. PLOS One 2014;9(11).

73. Ost DE, Poch D, Fadel A, Wettimuny S, Ginocchio C, Wang X-P. Minibronchoalveolar lavage quantitative polymerase chain reaction for diagnosis of methicillin-resistant Staphylococcus aureus pneumonia. Crit Care Med [Internet] 2010;38(7):1536-41. Available from: http://www.ncbi.nlm.nih.gov/pubmed/20473148

74. Gadsby N, Hellyer T, Mcmullan R, et al. 16S pan-bacterial PCR can accurately identify patients with ventilator associated pneumonia. Thorax [Internet] 2016;Available from:

http://www.embase.com/search/results?subaction=viewrecord\&from=export\&i d=L71630018\%5Cnhttp://dx.doi.org/10.1007/s00134-013-34515\%5Cnhttp://elvis.ubvu.vu.nl:9003/vulink?sid=EMBASE\&issn=03424642\&id=d oi:10.1007\%2Fs00134-013-3451-5\&atitle=16S+pan-bacterial $+P$

75. Assicot M, Gendrel D, Carsin H, Raymond J, Guilbaud J, Bohuon C. High serum procalcitonin concentrations in patients with sepsis and infection. Lancet (London, England) [Internet] 1993;341(8844):515-8. Available from: 
http://www.ncbi.nlm.nih.gov/pubmed/8094770

658 76. Becker KL, Snider R, Nylen ES. Procalcitonin in sepsis and systemic inflammation: A harmful biomarker and a therapeutic target. Br J Pharmacol 2010;159(2):253-264.

661 77. Filipiak W, Filipiak A, Ager C, Wiesenhofer H, Amann A. Optimization of sampling parameters for collection and preconcentration of alveolar air by needle traps. J Breath Res [Internet] 2012;6(2):27107. Available from: http://stacks.iop.org/1752-

665 7163/6/i=2/a=027107? $\mathrm{key}=$ crossref $.4 \mathrm{c} 1053321294512 \mathrm{bd} 66677 \mathrm{cb} 52135658$

666 667 668 669 670 671 672 673 674 675 676 677 678 679 680 681 682 683
78. Schubert JK, Miekisch W. Breath Analysis in Critically III Patients-Potential and Limitations. Volatile Biomarkers [Internet] 2013;155-176. Available from: http://linkinghub.elsevier.com/retrieve/pii/B978044462613400009X

79. Horváth I, Barnes PJ, Loukides S, et al. A European Respiratory Society technical standard: exhaled biomarkers in lung disease. Eur Respir J [Internet] 2017;49(4):1600965. Available from:

http://erj.ersjournals.com/lookup/doi/10.1183/13993003.00965-2016

80. Bossuyt P, Reitsma J, Bruns D, et al. Towards complete and accurate reporting of studies of diagnostic accuracy : the STARD initiative. BMJ Br Med J 2003;326:41-44.

81. Bossuyt PM, Reitsma JB, Bruns DE, et al. STARD 2015: An updated list of essential items for reporting diagnostic accuracy studies. Clin Chem 2015;61(12):1446-1452.

82. Boots AW, Bos LD, Schee MP van der, Schooten FJ van, Sterk PJ. Exhaled Molecular Fingerprinting in Diagnosis and Monitoring: Validating Volatile Promises. Trends Mol. Med. 2015;21(10).

83. Chiu S-W, Wang J-H, Chang $\mathrm{K}-\mathrm{H}$, et al. A fully integrated nose-on-a-chip for rapid diagnosis of ventilator-associated pneumonia. IEEE Trans Biomed Circuits Syst 2014;8(6):765-778. 
685 84. Rock F, Barsan N, Weimar U, Röck F, Barsan N, Weimar U. Electronic nose:

686 Current status and future trends. Chem Rev [Internet] 2008;108(2):705-725.

$687 \quad$ Available from:

688 http://pubs3.acs.org/acs/journals/doilookup?in_doi=10.1021/cr068121q\%5Cnp 689 apers://316bc3e6-3d1b-427b-a4e3-80bd1b4d480e/Paper/p1578

690 85. Bean HD, Zhu J, Hill JE. Characterizing bacterial volatiles using secondary

691 electrospray ionization mass spectrometry (SESI-MS). J Vis Exp

$692 \quad 2011 ; 2(52): 3-6$.

693

694 
695

696

697 Table 1. Full text selected articles

698 The selected articles either concern clinical (C) or pre-clinical (P) studies.

699 Investigated inorganic compounds include nitric oxide (NO) and carbon monoxide

700 (CO). The investigated study population could be on ICU patients in general, or could

701 involve a specific target group, e.g. patients with COPD (Chronic obstructive

702 pulmonary disease), Community-acquired pneumonia (CAP) or Ventilator-associated

703 pneumonia (VAP). As a reference test a protected specimen brush (PSB),

704 bronchoalveolar lavage (BAL) or endotracheal aspirate (ETA) was used. The used

705 index test to analyse Volatile Organic Compounds (VOCs) could involve secondary

706 electrospray ionization - mass spectrometry (SESI-MS), Clinical Pulmonary Infection

707 Score (CPIS), eNose technology or gas chromatography - mass spectrometry (GC-

708 MS): either sensitivity (sens) and specificity (spec), or accuracy has been displayed

709 in the Table.

710 *For details: see Table 3.

711

712 Table 3. VOCs identified by GC-MS: The VOCs are either increased ( $\uparrow$ ) or

713 decreased $(\downarrow)$ in the exhaled breath of pneumonia patients when compared to

714 patients without pneumonia. 


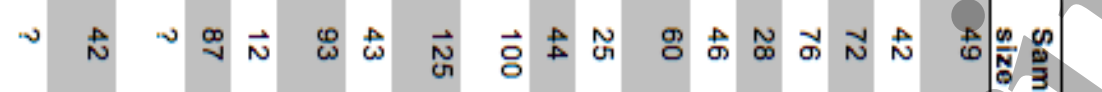

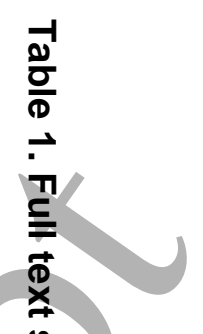

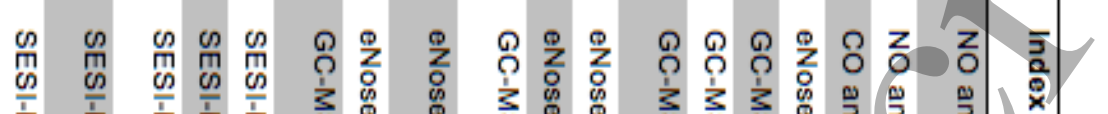

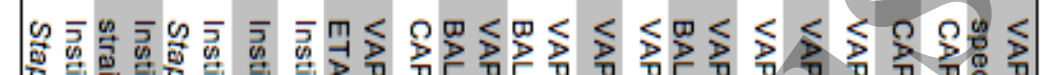

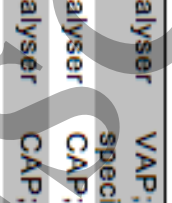

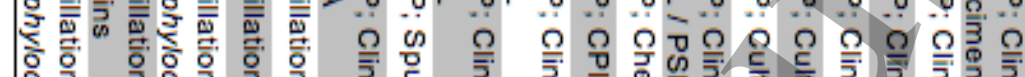
के के

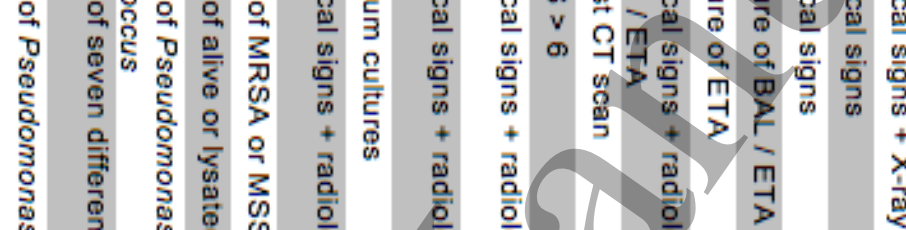

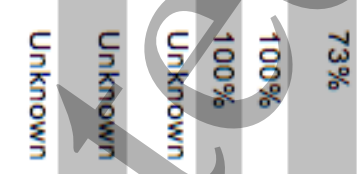

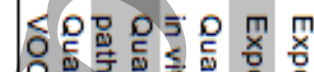

क

क

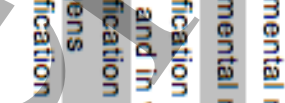

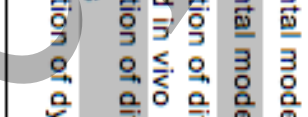

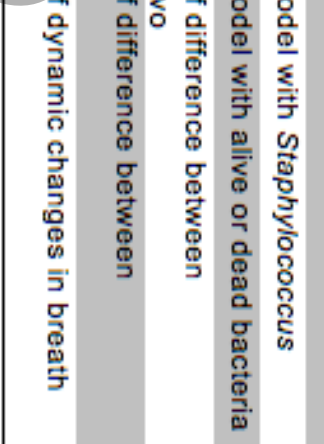

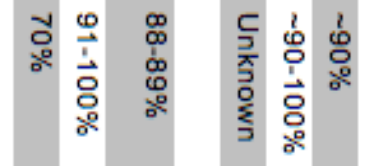

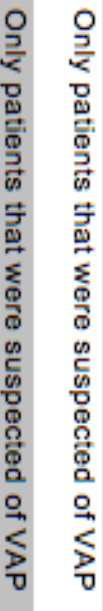
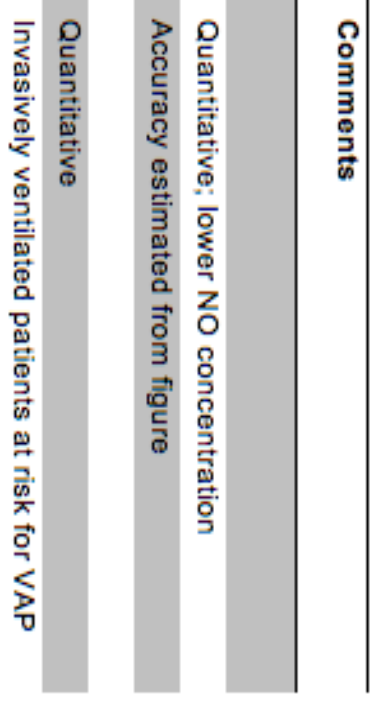
Table 2. QUADAS-2 (adapted version)

\begin{tabular}{|c|c|c|c|c|c|}
\hline \multirow[t]{2}{*}{ Study } & \multicolumn{3}{|c|}{ Risk of Bias } & \multirow[b]{2}{*}{$\begin{array}{l}\text { Reference } \\
\text { standard }\end{array}$} & \multirow[b]{2}{*}{$\begin{array}{l}\text { Flow and } \\
\text { timing }\end{array}$} \\
\hline & Year & $\begin{array}{l}\text { Patient } \\
\text { selection }\end{array}$ & $\begin{array}{l}\text { Index } \\
\text { test }\end{array}$ & & \\
\hline Adrie $^{31}$ & 2001 & No & No & No & No \\
\hline Ali-Ali ${ }^{32}$ & 2001 & Yes & Yes & Yes & No \\
\hline Bean $^{44}$ & 2014 & $\mathrm{~N} / \mathrm{A}$ & Yes & No & No $O$ \\
\hline Bean $^{45}$ & 2015 & $N / A$ & Yes & No & No \\
\hline Biernacki ${ }^{33}$ & 2001 & Yes & Yes & Yes & No \\
\hline Chiu $^{83}$ & 2014 & Yes & Yes & Yes & Unc \\
\hline Filipiak $^{46}$ & 2015 & Yes & Yes & No & No \\
\hline Fowler 35 & 2015 & Unclear & Yes & No & No \\
\hline Gao $^{47}$ & 2016 & Yes & Yes & No & No \\
\hline Hockstein ${ }^{37}$ & 2004 & Yes & Yes & Yes & No \\
\hline Hockstein ${ }^{38}$ & 2005 & Yes & Yes & Yes & No \\
\hline Schnabel ${ }^{34}$ & 2015 & Unclear & Yes & & No \\
\hline Schnabel $^{40}$ & 2015 & No & Yes & 10 & No \\
\hline Van Geffen ${ }^{39}$ & 2016 & Yes & Yes & & No \\
\hline Van Oort ${ }^{36}$ & 2017 & No & Yes & & No \\
\hline Zhu $^{42}$ & 2013 & $N / A$ & Yes & & No \\
\hline $\mathbf{Z h u}^{41}$ & 2013 & $N / A$ & Yes & iv & No \\
\hline Zhu $^{43}$ & 2013 & $N / A$ & 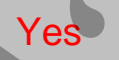 & No & No \\
\hline
\end{tabular}


Table 3. VOCs identified by GC-MS: increased $(\uparrow)$ or decreased $(\downarrow)$ in breath of pneumonia vs. no pneumonia patients

\begin{tabular}{|c|c|c|c|}
\hline \multirow[t]{2}{*}{ Classification } & \multirow[t]{2}{*}{ Volatile Organic Compound } & \multicolumn{2}{|c|}{ Reporting article } \\
\hline & & Fowler ${ }^{35}$ & Van Oort ${ }^{36}$ \\
\hline \multirow[t]{3}{*}{ Ketone } & Acetone & & $\downarrow$ \\
\hline & 2-methyl cyclopentanone & $\downarrow$ & \\
\hline & Methylisobutylketone & & \\
\hline \multirow[t]{3}{*}{ Aldehyde } & Acrolein & & \\
\hline & Nonanal & & \\
\hline & Tetradecanal & & \\
\hline \multirow[t]{2}{*}{ Ether } & Sevoflurane & & $\downarrow$ \\
\hline & Tetrahydrofuran & & \\
\hline \multirow[t]{7}{*}{ Alkane } & 2-methyl butane & & \\
\hline & 2-ethoxy-2-methyl propane & & $\downarrow$ \\
\hline & Carane & & \\
\hline & Dodecane & & \\
\hline & Heptane & $\downarrow$ & \\
\hline & Tetradecane & & \\
\hline & 2,6,11,15-tetramethy & $\uparrow$ & \\
\hline Alkene & Cyclohexene & & $\downarrow$ \\
\hline Terpene & 3-carene & $\uparrow$ & \\
\hline \multirow[t]{4}{*}{ Alcohol } & Ethanol & $\downarrow$ & \\
\hline & Isopropyl Alcohol & & \\
\hline & Hexafluoroisopropanol & & $\downarrow$ \\
\hline & 1-propanol & & $\downarrow$ \\
\hline Arene & Ethylbenzene & & \\
\hline Ester & N-butyric acid 2-ethylhexyl ester & $\uparrow$ & \\
\hline Sulfide & Carbon disulfide & & $\downarrow$ \\
\hline Amide & N-cyclohexyl-N'(2-hydroxyethyl)thio-urea & $\downarrow$ & \\
\hline
\end{tabular}




\section{Figure Legends}

Figure 1. The aspired contribution of breath analysis regarding antibiotic stewardship for pneumonia ( $\uparrow$ : increase)

\section{Figure 2.}

Exhaled breath analysis for the prediction of pneumonia: several available techniques and accompanying analytical principles.

eNose: Conventional electronic noses consist of an array of gas sensors using transducer principles (e.g. through metal oxide sensors, conducting polymer sensors or surface or bulk acoustic wave sensors) ${ }^{84}$, whereas new approaches involve optical sensor systems and colorimetric sensors ${ }^{17}$; GC-MS: Gas chromatography - mass spectrometry is currently seen as the preferred method for separation, detection and identification of individual VOCs; SESI-MS: Secondary electrospray ionization mass spectrometry enables rapid detection of VOCs without the need for sample pretreatment ${ }^{85}$. After introduction into the SESI reaction chamber the sample passes through an electrospray cloud that ionizes the volatiles, after which the ionized VOCs are detected in the mass spectrometer. The method cannot be used to quantify individual VOCs, as many volatiles have similar molecular weights and the methodology relies on pattern recognition. GC-MS and SESI-MS can both be used for targeted and untargeted analysis.

Figure 3. Flow diagram of article selection.

VOC: Volatile Organic Compound; GC-MS: Gas chromatography - mass spectrometry; SESI-MS: Secondary electrospray ionization - mass spectrometry. 


\section{Figures}

Figure 1

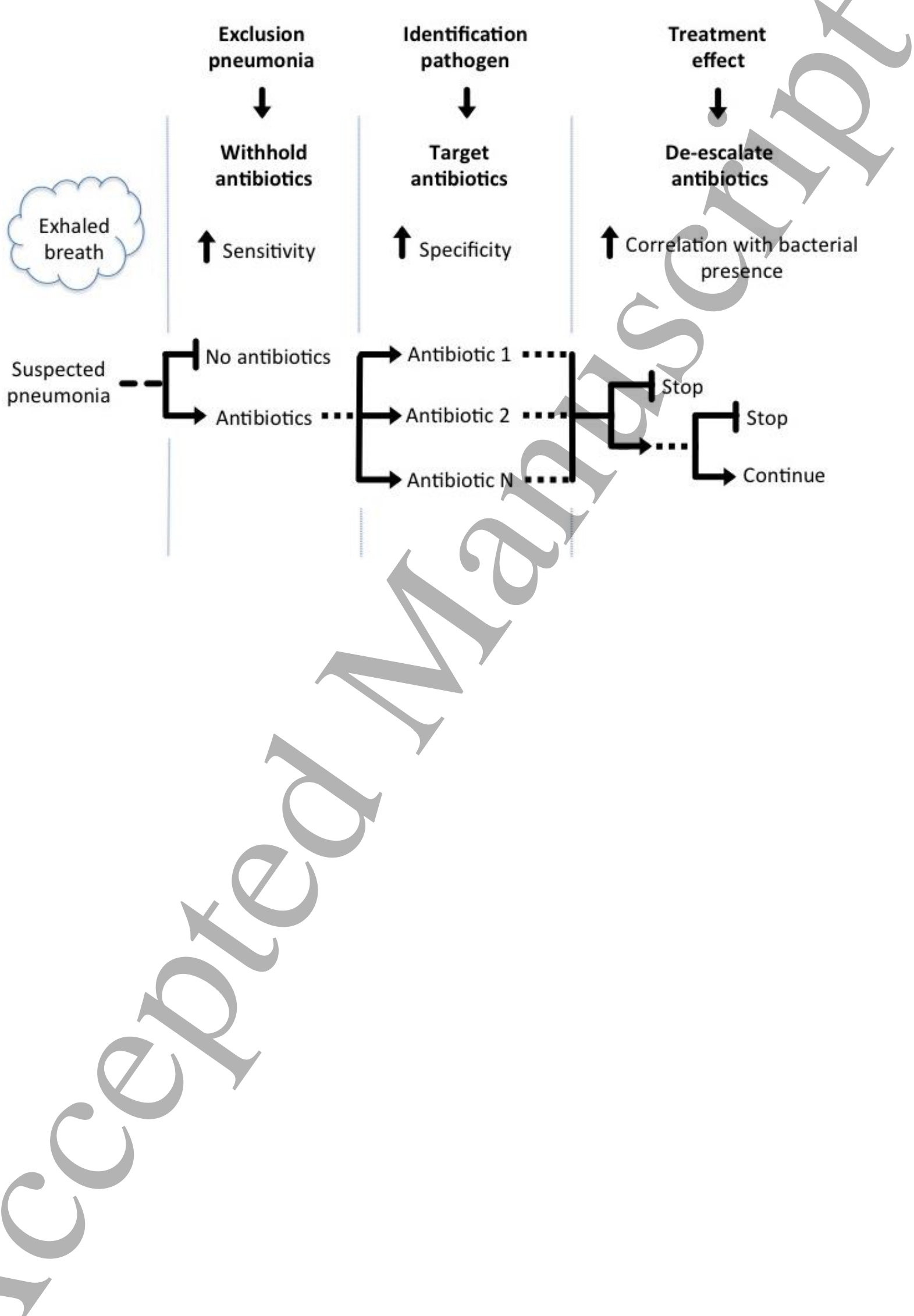


Figure 2.

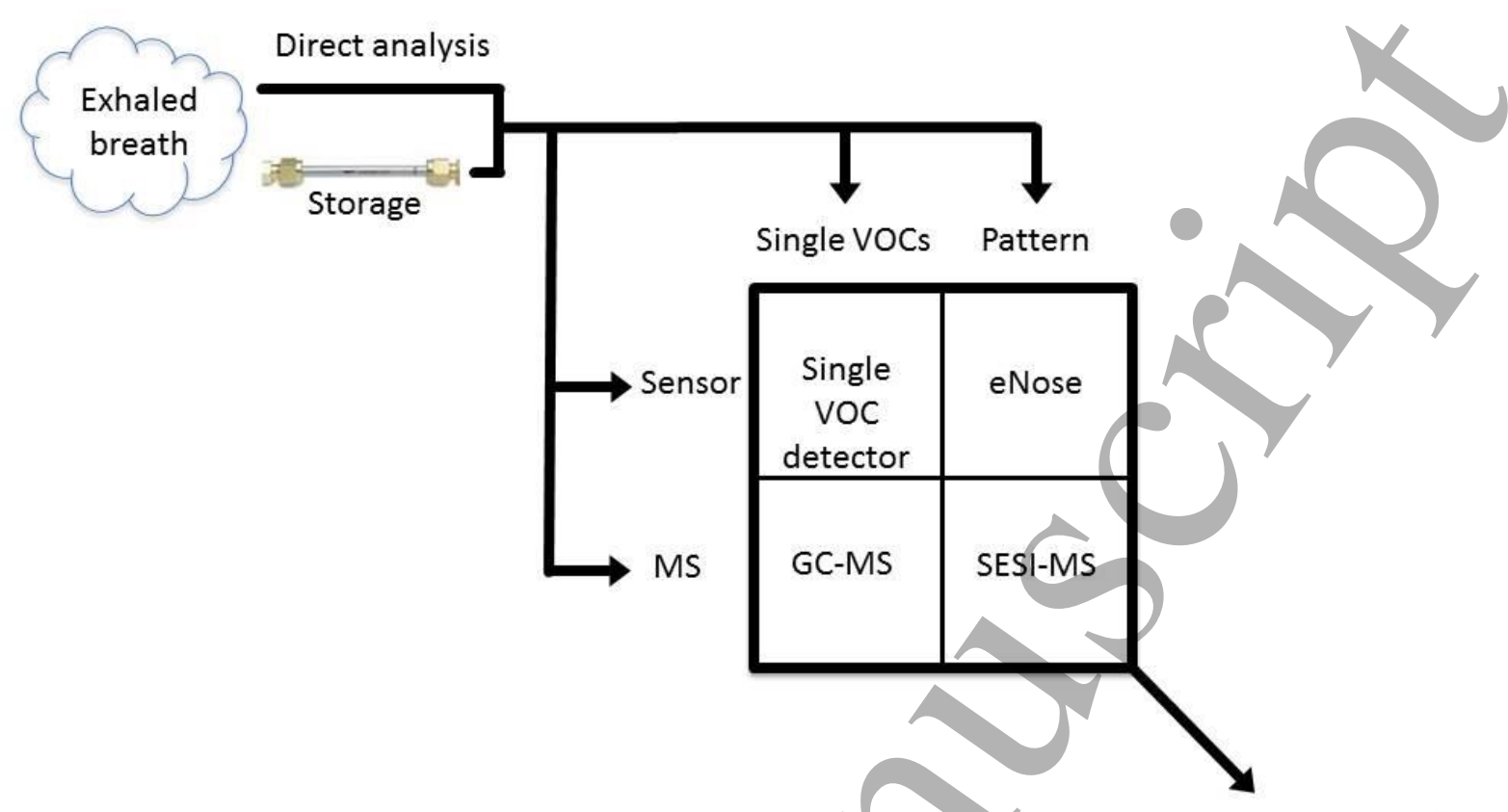

Recognition of pneumonia 
Figure 3.

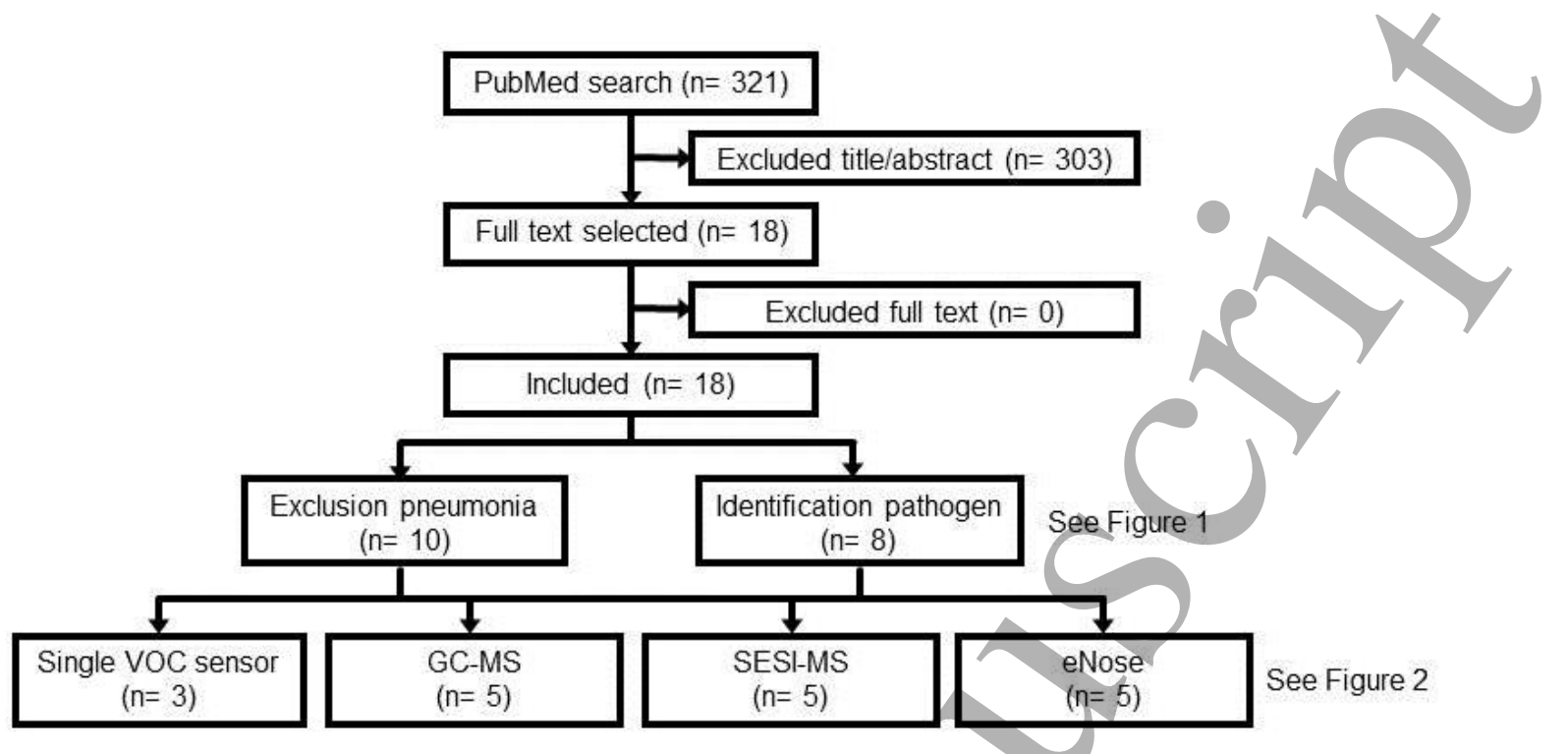

